\title{
Erratum: Reviewer Acknowledgment
}

The Editorial Office would like to apologize for unintentionally omitting the following reviewer names from the March/April 2001 issue of Genetics in Medicine. It was our mistake and we deeply apologize for this. The Editors of Genetics in Medicine would like to thank all of the individuals who have provided reviews of manuscripts over the past year. These reviews have been critical to our mission of enhancing the knowledge and practice of medical genetics through the publication of highquality papers in Genetics in Medicine.

Lorenzo Botto, MD

Michele Caggana, ScD

Louis J. Elsas, MD

Michelle Fox, MS

Karen Greendale, MA, CGC

Susan Hayflick, MD

Bonnie LeRoy, MS

Angela E. Lin, MD

Jeanne Meck, $\mathrm{PhD}$
Roberta A. Pagon, MD

Reed Pyeritz, MD, PhD

Jerome Rotter, MD

Stuart Schwartz, PhD

Lisa Gail Shaffer, PhD

Roger Stevenson, MD

Georgia L. Wiesner, MD

Daynna Wolff, PhD 